\title{
LIFE CYCLE COST MODELLING OF BUILDINGS WITH CONSIDERATION OF THE RISK
}

\author{
E. PLEBANKIEWICZ ${ }^{1}$, K. ZIMA ${ }^{2}$, D. WIECZOREK ${ }^{3}$
}

\begin{abstract}
The paper presents an approach to evaluating a building throughout its whole life cycle in relation to its sustainable development. It describes basic tools and techniques of evaluating and analysing the costs in the whole life cycle of the building, such as Life Cycle Assessment, Life Cycle Management, Life Cycle Cost and Social Life Cycle Assessment. The aim of the paper is to propose a model of cost evaluation throughout the building life cycle. The model is based on the fuzzy sets theory which allows the calculations to include the risks associated with the sustainable development, with the management of the investment and with social costs. Costs incurred in the subsequent phases of the building life cycle are analysed and modelled separately by means of a membership function. However, the effect of the analysis is a global cost evaluation for the whole life cycle of the building.
\end{abstract}

Keywords: Life Cycle Assessment, Life Cycle Cost, Fuzzy sets, Investment costs

\section{INTRODUCTION}

Considering construction products, sustainable development can be evaluated on the level of the functional unit, which is a building or its component parts (elements or construction works). This view is shared, among others, by the CEN/TC 350 - a technical body of the European Committee for Standardization, which is responsible for the development of the European standardised

\footnotetext{
${ }^{1}$ Prof., DSc., PhD., Eng., Cracow University of Technology, Institute of Construction and Transportation Engineering \& Management, 24 Warszawska Street, 31-155 Cracow, Poland, e-mail: eplebank@izwbit.pk.edu.pl

${ }^{2}$ PhD., Eng., Cracow University of Technology, Institute of Construction and Transportation Engineering \& Management, 24 Warszawska Street, 31-155 Cracow, Poland, e-mail: kzima@izwbit.pk.edu.pl

${ }^{3}$ MSc., Eng., Cracow University of Technology, Institute of Construction and Transportation Engineering \& Management, 24 Warszawska Street, 31-155 Cracow, Poland, e-mail: dwieczorek@izwbit.pk.edu.pl
} 
methods for assessing the sustainable development of buildings. The standards are to become the basis of an analysis and assessment of the compatibility of the building with the principles of sustainable development due to environmental, social and economic factors. For this purpose one needs to use analyses of the life cycles of buildings and the adopted quantifiable indicators of evaluation. The analyses of the building's life cycle allow taking into consideration numerous criteria for a single construction product. Yet in fact a particular element of a building tendsto consist of several products, so it seems that the most appropriate solution involves an assessment of completed elements or a building as a whole. The paper presents a method of a global assessment of the building throughout its life cycle, based on basic evaluation criteria using elements of the fuzzy sets theory. The computational model based on building life cycle costs includes the risk involved in every phase of the life cycle. The model employs the fuzzy sets theory to model unclear, imprecise or incomplete information.

\section{LITERATURE OVERVIEW}

There have been many publications concerning cost analysis and attempts to establish the costs of building objects, including the building life cycle costs. The specificity of buildings is the reason for the appearance of uncertainty and risks related to the costs incurred at every stage of the building life cycle. Various attempts to account for the risk can be found in the literature.

Frangopol, Lin and Estes [5] presented a strategy optimization method of element repair in the life cycle of concrete bridge girders which, when undergoing corrosion during use, may cause malfunctioning of the structure. The optimal strategy for repair is achieved through minimizing the expected total life-cycle cost which encompasses investment costs, maintenance costs, as well as the costs of supervision, repair and break-down. The authors associate all the cost types with the probability of a malfunction which may, or may not, be diagnosed during the planned supervision of the construction.

Sobanjo [15] in his work presented a fuzzy sets-based methodology for life-cycle cost analysis of facilities that contained data related to initial, rehabilitation, sale/demolition, operating and maintenance costs. A conceptual methodology has been presented to illustrate how the uncertainties introduced due to the subjective estimation of cost variables, typically based on expert opinions, can be handled in life cycle cost analysis of facilities.

Fuller and Boyles [7] presented techniques for dealing with uncertainty probabilistic techniques. They used the Monte Carlo simulation as a simple technique of sampling the probability distributions of 
uncertain input values to obtain a close approximation to the true probability distribution of a measure of worth. Cost elements that were taken into account included purchase and installation costs, residual value, annual electricity cost, annual operating and maintenance costs and repair cost.

The paper by Menassa [12] presented a way of estimating the values of investment costs related to the modernization of the existing buildings as far as sustainable development was concerned. The author accounted for uncertain events associated with a negative influence of the existing risk on the value of life cycle costs, and with the expected profits that the investment could bring.

Numerous publications depict various methods of calculating the costs of the whole life cycle of a building or a part of it using, for example, genetic algorithms [19], the AHP method [21] or the parallel cost calculation [16]. The issue of risk in such calculations was discussed in [4], [14] and [13].

\section{LIFE CYCLE OF A BUILDING}

The integrated product approach is now regarded as the most effective way to implement the environmental dimension for products. The approach is based on five basic principles:

- thinking in terms of a life cycle,

- cooperation with the market,

- the involvement of the participants,

- continuation of improvement by making frequent adjustments,

- differentiation of policy instruments.

The introduction of the idea of thinking in terms of a building life cycle resulted in the need to use appropriate tools and techniques for assessing and analysing costs throughout the life cycle of the building. These methods include the following:

- Life Cycle Assessment - LCA,

- Life Cycle Management - LCM,

- Life Cycle Cost - LCC,

- Social Life Cycle Assessment - SLCA.

To determine the environmental burdens of buildings one should take into account the entire life cycle of building materials and products (LCA - Life Cycle Assessment). LCA is a complex and systematic method for analysing the impact of products and processes on human health and the environment throughout the product life cycle [17]. 
Life Cycle Management (LCM) has been employed in the management of construction projects in order to reduce the whole life cost, time and risk. LCM integrates each phase of project management from planning to close-out, making information sharing and coordination possible between owners, consultants, designers, contractors, and others [18]. The LCM of construction projects can be described as a management system for all the processes of a project [2], from planning, design, and construction to the commissioning, utilization, maintenance, and otherwise decommissioning of the project.

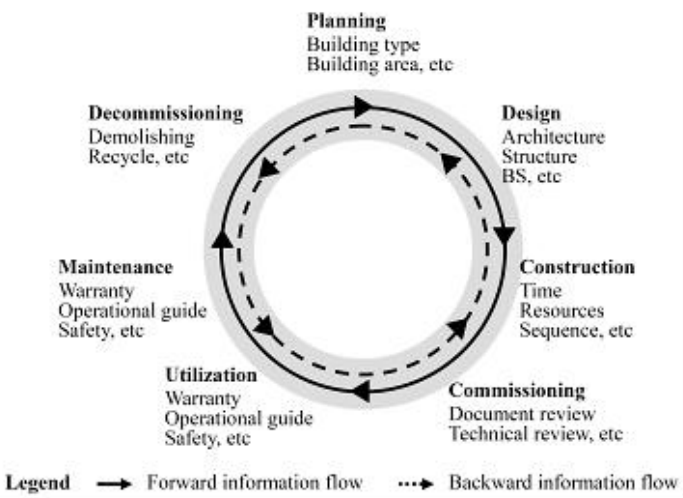

Fig. 1. The information flow of LCM of construction projects; source: [8]

Information flows should embrace the information concerning all the phases shown in Fig. 1. A lot of this information relates to planning, designing, construction, start up, utilization, maintenance and demolition. The information should be integrated to improve communication and cooperation. Information flows affect both the preceding and following phases. Once a decision is made, its influence on the preceding and following phases, and even on the whole life cycle, must be considered.

A social and socio-economic Life Cycle Assessment (S-LCA) is a social impact (and potential impact) assessment technique that aims to assess the social and socio-economic aspects of products and their potential positive and negative impacts along their life cycle encompassing extraction and processing of raw materials; manufacturing; distribution; use; re-use; maintenance; recycling; and final disposal [3]. Sample socio-economic factors evaluated during the SLCA analysis for the construction industry are presented in Table 1 . 
Table 1. Sample socio-economic factors; source: the authors based on [9]

\begin{tabular}{|c|c|c|}
\hline CATEGORIES & SUB-CATEGORIES & ASSESSMENT INDICATOR \\
\hline \multirow[t]{5}{*}{ Construction workers } & Freedom of association & $\begin{array}{l}\text { Respect for freedom of association } \\
\text { and collective bargaining }\end{array}$ \\
\hline & Work health and safety & $\begin{array}{l}\text { Accidents at work - individual and collective } \\
\text { security measures }\end{array}$ \\
\hline & Salaries & Fair wages above the minimum rates \\
\hline & Type of employment & Time, the lack of the so-called "junk contracts" \\
\hline & Discrimination & $\begin{array}{c}\text { Discrimination } \\
\text { among different groups of sex, age, etc. }\end{array}$ \\
\hline \multirow[t]{10}{*}{ Local community } & Safe and healthy living conditions & Lack of pollution \\
\hline & & Noise level \\
\hline & & Production waste \\
\hline & Access to raw materials & Using local raw materials \\
\hline & & Shaping the environment (landscape) \\
\hline & The use of the local workforce & Creating new jobs \\
\hline & & The use of local subcontractors \\
\hline & & Using a network of local suppliers \\
\hline & Acceptance of the local community & $\begin{array}{c}\text { Complaints and protests } \\
\text { on a new construction project }\end{array}$ \\
\hline & Cultural heritage & Protection of cultural heritage \\
\hline \multirow[t]{6}{*}{ Society } & Development of technologies & Development of technologies \\
\hline & & Transfer of technologies \\
\hline & & Research and development \\
\hline & Contribution to economic development & $\begin{array}{c}\text { The contribution of the new facility construction } \\
\text { to economic progress (GDP, income, wage levels, } \\
\text { unemployment, etc.) }\end{array}$ \\
\hline & & Development of the network of suppliers \\
\hline & & Development and support of subcontractors \\
\hline \multirow[t]{3}{*}{$\begin{array}{l}\text { Participants } \\
\text { in the investment }\end{array}$} & Fair competition & Monopoly and anti-competitive behaviour \\
\hline & & Timely payments \\
\hline & & Timely execution of investments \\
\hline
\end{tabular}

The sample socio-economic factors presented in Table 1 may generate some degree of risk. In particular, this refers to the factors associated with construction workers, that are work health and safety, salaries and type of employment.

\section{LIFE CYCLE COSTS}

The process presenting the life cycle of a building is shown in Fig. 2. 


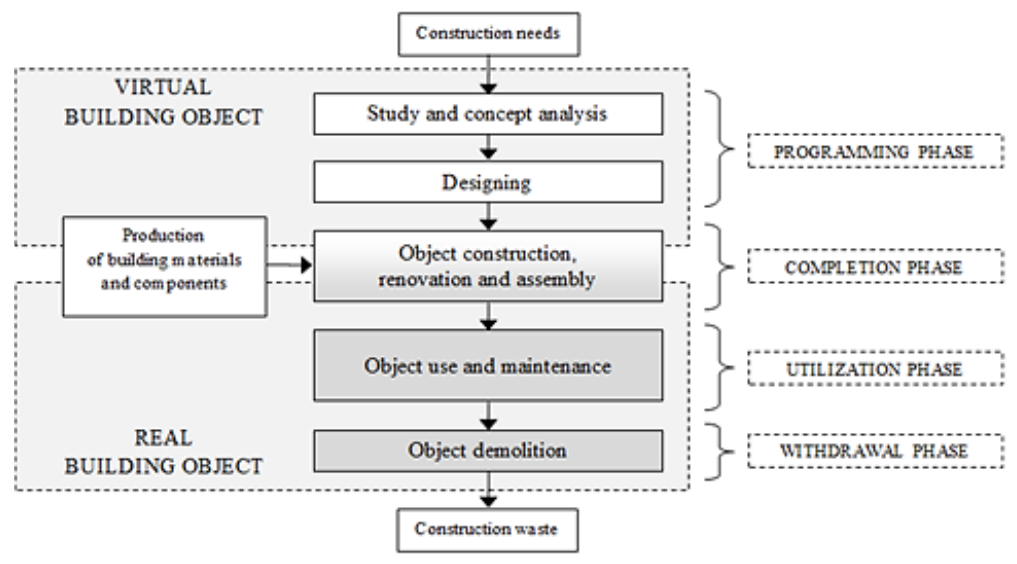

Fig. 2. The life cycle of a building; source: the authors based on [6] and [11]

The LCC analysis may be performed either by means of a simple method or a complex one.

The simple method should be used only for a simple comparison aiming at the selection of the optimal variant. The main drawback of this method is that it does not take into account the devaluation of money over time (discounting) or the change in energy prices.

The basis for calculating the life cycle costs (LCC) is the following formula:

$$
\mathrm{LCC}=\mathrm{C}_{\mathrm{pur}}+\left(\mathrm{T}_{\mathrm{sl}} \times \mathrm{C}_{\mathrm{en}}\right)
$$

where:

$\mathrm{C}_{\text {pur }}$ - purchase costs understood as the cost of a study analysis, design and execution when the product is a construction object $[\mathrm{PLN}], \mathrm{T}_{\mathrm{sl}}$ - service life [years], $\mathrm{C}_{\mathrm{en}}$ - annual energy cost [PLN/year]

The Royal Institution of Chartered Surveyors (RICS) in 2001 defined the life cycle cost of an asset as "the present value of the total cost of that asset over its operating life; including initial capital cost, occupation costs, operating costs and the cost or benefit of the eventual disposal of the asset at the end of its life". The LCC approach identifies all the future costs and benefits and reduces them to a current value with the use of discounting techniques by evaluating the economic value of the project. Costs analyses in the life cycle of a building include calculations of the costs of construction, maintenance and demolition.

The basic formula of calculating the life cycle cost (LCC) is as follows: 


$$
\mathrm{LCC}=\mathrm{C}+\mathrm{PV}_{\text {RECCURRING }}-\mathrm{PV}_{\text {RESIDUAL-VALUE }}
$$

where:

LCC - life cycle cost, C - construction cost in 0-year including hard cost (labour, materials, equipment, furnishings, etc.) and soft costs (design fees, permit fees, etc.), PV $\mathrm{V}_{\text {RECURRING }}$ - present value of all recurring costs (utilities, maintenance, replacements, service, etc.), $P V_{\text {RESIDUAL-VALUE }}$ - present value of the residual value (the expected value of the sale of an asset at the end of its estimated useful life) at the end of the study life

It is vital to specify all the costs in the whole life cycle of the building precisely, so that the decision about a construction investment is correct. The decision has to be based on a complete and reliable information about the costs.

\section{RISK FACTORS AT DIFFERENT STAGES OF THE LIFE CYCLE}

Risk factors, similarly to individual types of cost, may be ascribed to subsequent stages of a building's life cycle. A detailed classification of risks attributable to individual phases of the life cycle is presented in Table 2 .

Table 2. Division of risk factors attributable to individual phases of the life cycle, the case of residential and commercial buildings; source: the authors, based on [10], [14], [20] and [22]

\begin{tabular}{|c|c|c|c|c|c|}
\hline \multirow{2}{*}{ RISK CATEGORY } & \multirow{2}{*}{ RISK FACTORS } & \multicolumn{4}{|c|}{ LIFE CYCLE PHASES } \\
\hline & & $\mathrm{P}$ & $\mathrm{C}$ & $\mathrm{U}$ & W \\
\hline \multirow{9}{*}{ 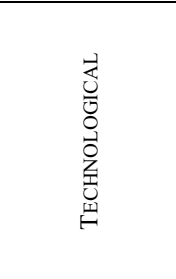 } & errors in designs & $\mathrm{X}$ & & & \\
\hline & deficiencies in designs & $\mathrm{X}$ & & & \\
\hline & incompliance of designs with the valid norms / legal provisions & $\mathrm{X}$ & & & \\
\hline & erroneously determined soil conditions & $\mathrm{X}$ & & & \\
\hline & erroneous assumptions for structural and materials solutions & $\mathrm{X}$ & & & \\
\hline & no technology available & $\mathrm{X}$ & $\mathrm{X}$ & & \\
\hline & errors in management & $\mathrm{X}$ & $\mathrm{X}$ & $\mathrm{X}$ & \\
\hline & shortage of qualified labour force & & $\mathrm{X}$ & & \\
\hline & efficiency of workers and equipment & & $\mathrm{X}$ & & \\
\hline \multirow{12}{*}{ 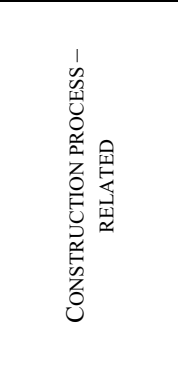 } & adverse weather conditions & & $\mathrm{X}$ & & $\mathrm{X}$ \\
\hline & accident rate in construction & & $\mathrm{X}$ & & $\mathrm{X}$ \\
\hline & occupational health and safety & & $\mathrm{X}$ & & $\mathrm{X}$ \\
\hline & definition of the scope of works & & $\mathrm{X}$ & & \\
\hline & changes in the planned scope of works & & $\mathrm{X}$ & & \\
\hline & quality of the completed works & & $\mathrm{X}$ & & \\
\hline & management quality & $\mathrm{X}$ & $\mathrm{X}$ & $\mathrm{X}$ & \\
\hline & delays in construction works completion & & $\mathrm{X}$ & & $\mathrm{X}$ \\
\hline & failure to keep the deadlines & $\mathrm{X}$ & $\mathrm{X}$ & & $\mathrm{X}$ \\
\hline & failure to pay the due consideration to subcontractors and suppliers & & $\mathrm{X}$ & & \\
\hline & availability of reliable subcontractors & & $\mathrm{X}$ & & \\
\hline & cooperation with subcontractors and suppliers & & $\mathrm{X}$ & & \\
\hline
\end{tabular}




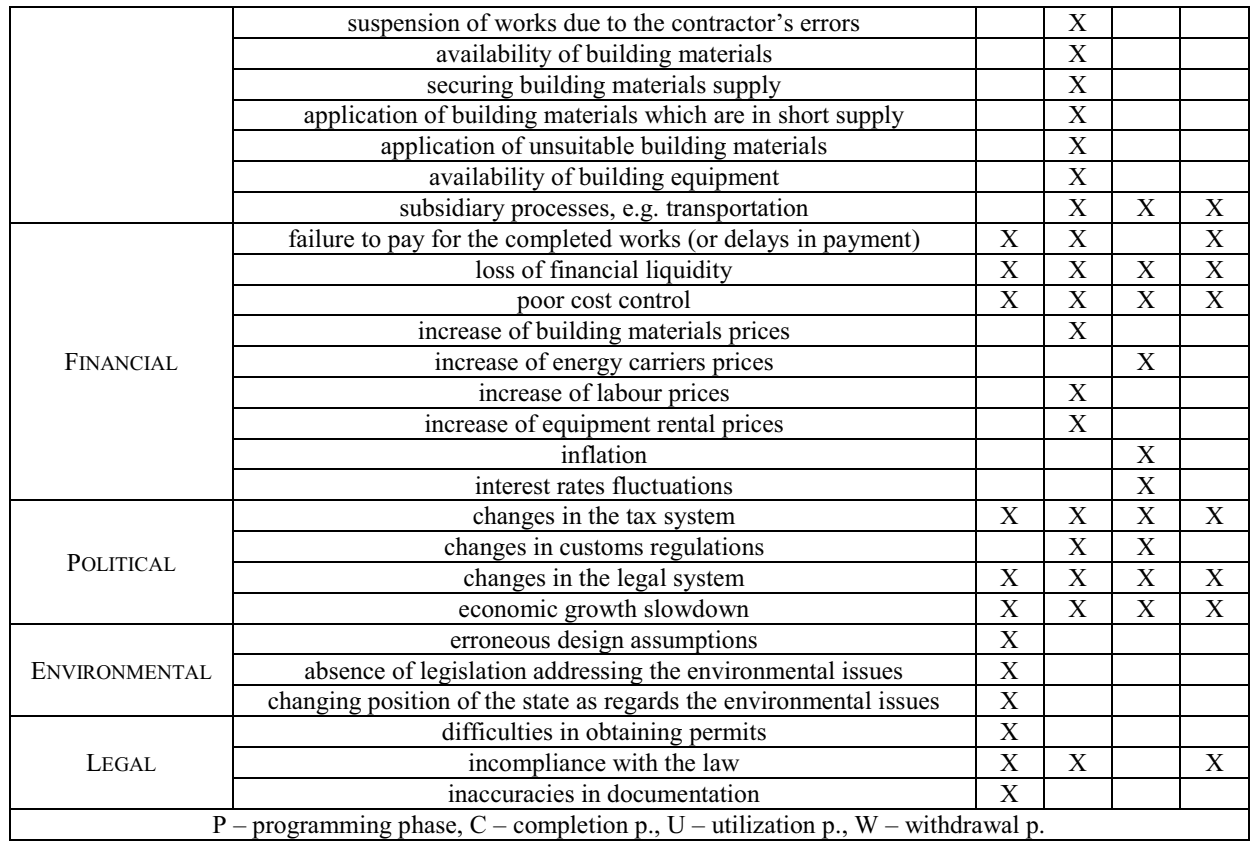

\section{PRoCEDURE FOR DETERMINING THE LIFE CYCLE COST WITH CONSIDERATION OF THE RISK}

The algorithm procedure for determining the costs of a building during its life cycle, which includes the impact of the risk factors currently occurring on the value of the cost, as shown in Fig. 3. This algorithm, created by the authors, is used to evaluate life cycle scenarios and enables the comparison and selection of the best strategy for the management of a building in its life cycle. In the construction industry, the basic stages of project completion are the following: the programming phase, the completion phase, the utilization phase and the withdrawal phase. Each of the above mentioned phases of the life cycle may be accompanied by some characteristic internal IP processes (e.g. supervision, monitoring, controlling the construction execution or utilization of the building object).

While analyzing the cost of the product life cycle, one must first define precisely the types of costs (marked $\mathrm{C}$ on a diagram), and also identified risk factors (marked $\mathrm{R}$ ), which may have an impact on the final value of the cost, causing for instance, their growth. Second, one should precisely determine the value of the cost and the size of the impact of risk factors on costs. 
The value of life cycle cost may be acceptable and the impact of the risks might be low. If so, this will result in passage along the "Yes" direction of the algorithm, in which case the result is the life cycle scenario with the designated life cycle cost LCC. However, this may lead to a situation in which one of the phases of the life cycle, the calculated values of costs or impact risk levels assume values that are far from satisfactory. Therefore, experts have the opportunity at any stage of a detailed analysis to return to the previous step and to correct assumptions to be analyzed. In extreme cases, for instance, when the value of the cost or impact on the value of risk are high, one may choose to refrain from further construction life cycle scenarios and move towards the "No" directions that is, from the programming phase to the withdrawal phase via the abandonment, or from the utilization phase to the withdrawal phase through demolition or resale.

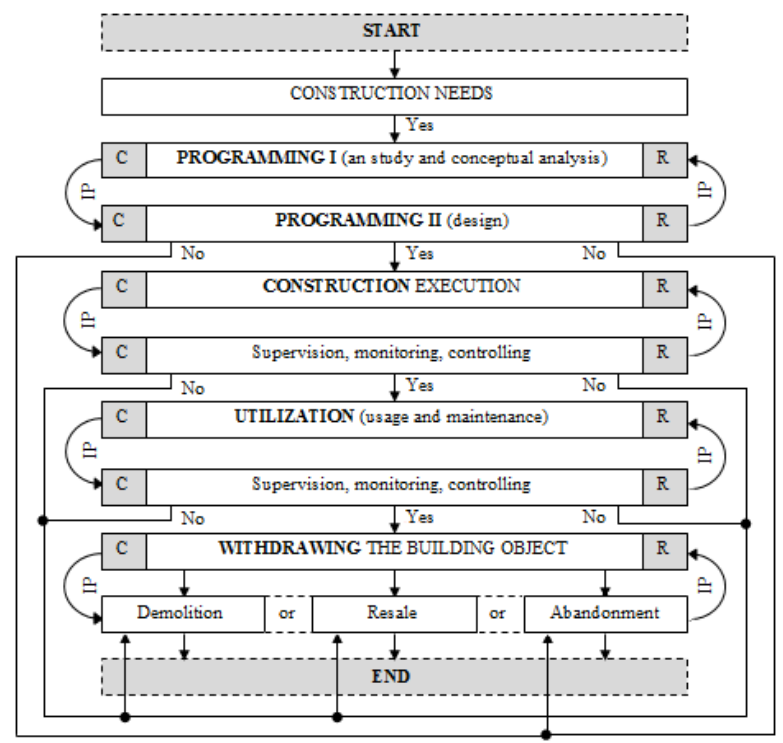

Fig. 3. A diagram of a process of determining the life cycle cost of a building with consideration of the risk; source: the authors

\section{FUZZY SETS-BASED METHOD}

One of the methods of accounting for the risk in the life cycle of the building uses fuzzy logic, thanks to which cost values may assume a fuzzy form with a properly chosen membership function. This paper presents the procedure described in [1]. 
The model incorporates the equivalent annual cost method along with the Day-Stout-Warren (DSW) algorithm and the vertex method to evaluate competing alternatives.

The fuzzy-based LCC model is proposed in the following steps:

1. Express uncertain variables as fuzzy quantities, using user defined membership functions satisfying normality and convexity. Various groups of costs are represented by a different membership function. For reasons of simplicity, the example here involves a trapezoidal membership function for all data, in accordance with Fig. 4.

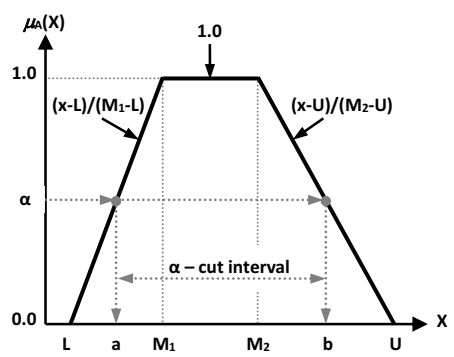

Fig. 4. Trapezoidal membership function with $\alpha$-cut; source: the authors

2. Select a value for $\alpha$-cut, such that $0 \leq \alpha \leq 1.0$.

3. Find the interval of the discount rate corresponding to the selected value of $\alpha$ in step 2 .

4. For each competing alternative, find the intervals of the parameters associated with cost data corresponding to the selected value of $\alpha$. These include initial cost, annual costs, values and timings of future costs, salvage value, and service life.

5. Use the vertex method to calculate the corresponding intervals of discounting factors using Eq. (7.1) and Eq. (7.2), and Eq. (7.3) to calculate the corresponding intervals of the capital recovery factor.

$$
\mathrm{PWF}_{\mathrm{ij}}=\frac{1}{(1+\mathrm{r})^{\mathrm{t}_{\mathrm{ij}}}}
$$

where:

$\mathrm{PWF}_{\mathrm{ij}}$ - present worth factor of an irregular future cost, $\mathrm{r}$ - discount rate, $\mathrm{t}_{\mathrm{ij}}$ - time at which the irregular future cost has been incurred 


$$
\mathrm{PWF}_{\mathrm{i}}=\frac{1}{(1+\mathrm{r})^{\mathrm{T}_{\mathrm{i}}}}
$$

where:

$\mathrm{PWF}_{\mathrm{i}}$ - present worth factor of salvage value, $\mathrm{T}_{\mathrm{i}}-$ service life of alternative $\mathrm{i}$

$$
\mathrm{CRF}_{\mathrm{i}}=\frac{\mathrm{r} \cdot(1+\mathrm{r})^{\mathrm{T}_{\mathrm{i}}}}{(1+\mathrm{r})^{\mathrm{T}_{\mathrm{i}}}-1}
$$

where:

$\mathrm{CRF}_{\mathrm{i}}$ - capital recovery factor that converts the $\mathrm{NPV}_{\mathrm{i}}$ into its $E A C_{i}$

6. Use Eq. (7.4) to compute the NPW and Eq. (7.5) to compute the corresponding EAC based on the rules of interval calculations.

$$
\mathrm{NPW}_{\mathrm{i}}=\mathrm{IC}_{\mathrm{i}}+\sum_{\mathrm{j}=1}^{\mathrm{NF}}\left(\mathrm{FC}_{\mathrm{ij}} \cdot \mathrm{PWF}_{\mathrm{ij}}\right)-\mathrm{SV}_{\mathrm{i}} \cdot \mathrm{PWF}_{\mathrm{i}}
$$

where:

$\mathrm{IC}_{\mathrm{i}}$ - initial cost, $\mathrm{FC}_{\mathrm{ij}}$ - future costs, $\mathrm{SV}_{\mathrm{i}}$ - salvage value (SV)

$$
\mathrm{EAC}_{\mathrm{i}}=\mathrm{AC}_{\mathrm{i}}+\mathrm{NPW}_{\mathrm{i}} \cdot \mathrm{CRF}_{\mathrm{i}}
$$

where:

$\mathrm{AC}_{\mathrm{i}}$ - annual operating and maintenance costs

7. Repeat steps 4 to 6 for all alternatives being considered.

8. Repeat steps 2 to 7 for other values of $\alpha$-cuts.

9. For the defuzzification process the area compensation method will be used. Compute the $\mathrm{R}$ value Eq. (7.6) for each alternative based on its EAC membership function.

$$
\mathrm{R}_{\mathrm{A}}=\frac{\left(\mathrm{A}_{1}+\mathrm{A}_{\mathrm{R}}\right)}{2}
$$


where:

$A_{1}$ and $A_{r}-$ the areas bounded by the left and right curves of the fuzzy set $A$ and the vertical axis

10. Rank alternatives according to their $R$ values.

\subsection{COMPUTATIONAL EXAMPLE}

In the example the costs of life cycle of a multi-family building were compared, taking into account the main groups of the costs described above. Two variants of building implementation were selected. In one of them, the building had been constructed in the traditional technology, so it was assumed that the costs were to a large extent predictable. Therefore, the computation involved sharp cost values and LCC was determined by means of the deterministic method of specifying the efficiency of the investment, on the basis of discounted money flows, taking into account environmental issues LCNPV - Life Cycle Net Present Value.

The other variant involved the HVAC (stands for heating, ventilation and air conditioning) system. HVAC is a control system that applies regulation to a heating and/or air conditioning system. The costs associated with this system are hard to predict due to the risks involved. The characteristic risk factors in this case may include, for example, the use of rare, specialized systems that link heating, ventilation and air conditioning during the building implementation phase and the limited availability of specialist servicing companies for HVAC systems.

Due to these conditions the cost values were provided in a fuzzy form with a membership function as in Fig. 4. The output data assumed for the calculations are presented in Table 3.

Table 3. Data used in analysis; source: the authors

\begin{tabular}{|c|c|c|c|c|c|}
\hline & \multirow{2}{*}{$\begin{array}{c}\text { VARIANT 1 } \\
\text { Multifamily residential } \\
\text { building 5-storey, traditional } \\
\text { technology }\end{array}$} & \multicolumn{4}{|c|}{$\begin{array}{c}\text { VARIANT } 2 \\
\text { Multifamily residential building 5-storey, } \\
\text { the HVAC system }\end{array}$} \\
\hline & & $\mathrm{L}$ & M1 & M2 & $\mathrm{U}$ \\
\hline Investment costs [PLN] & 13445333 & 18000000 & 19000000 & 20000000 & 21000000 \\
\hline Operating costs [PLN] & $\begin{array}{l}210374 \\
\text { per year }\end{array}$ & 92512 & 95200 & 99000 & $\begin{array}{l}100230 \\
\text { per year }\end{array}$ \\
\hline $\begin{array}{c}\text { Cost of demolition } \\
\text { [PLN] }\end{array}$ & $\begin{array}{c}750190 \\
\text { after } 30 \text { years of use }\end{array}$ & & & & \\
\hline Profits (resale) [PLN] & & 2500000 & 2000000 & 1000000 & 500000 \\
\hline Discount rate [\%] & 6 & 3 & 4 & 6 & 8 \\
\hline Life cycle [years of use] & 30 & 30 & 35 & 40 & 50 \\
\hline
\end{tabular}


For the first variant, the LCNPV value was calculated with the use of the following Eq. (7.7) and $\mathrm{R}$ value with the use of Eq. (7.8):

$$
\mathrm{LCNPV}=\sum_{\mathrm{i}=0}^{\mathrm{n}} \frac{\mathrm{CF}_{\mathrm{i}}}{(1+\mathrm{r})^{\mathrm{i}}}
$$

where:

$\mathrm{CF}$ - cash flow in $\mathrm{i}$-th year, $\mathrm{n}$ - number of years involved in a life cycle, $\mathrm{i}$ - subsequent year, $\mathrm{r}$ - discount rate

$$
\mathrm{R}=\operatorname{LCNPV} \cdot \frac{\mathrm{r} \cdot(1+\mathrm{r})^{\mathrm{t}}}{(1+\mathrm{r})^{\mathrm{t}}-1}
$$

where:

$\mathrm{R}$ - capital recovery that converts the LCNPV into its EAC

For the first variant:

$$
\begin{gathered}
\mathrm{LCNPV}=25368553 \text { PLN } \\
\mathrm{R}_{1}=1842998 \text { PLN }
\end{gathered}
$$

For the second variant, the mathematical calculations presented in this paper represent an analysis for a selected value of $\alpha$-cut (0.3). The corresponding interval values [a, b] for $\alpha$-cut $=0.30$ for all problem variables are given in Table 4 .

Table 4. Interval values for parameters; source: the authors

\begin{tabular}{|c|c|c|}
\hline PARAMETER & $\mathrm{a}$ & $\mathrm{b}$ \\
\hline Investment costs [PLN] & 18300000 & 20700000 \\
\hline Operating costs [PLN] & 93318 & 99861 \\
\hline Cost of demolition [PLN] & 2350000 & 650000 \\
\hline Discount rate [\%] & 3,3 & 7,4 \\
\hline Life cycle [years of use] & 31,5 & 47 \\
\hline
\end{tabular}

The $\mathrm{PWF}_{1}$ for the resale profit is calculated using the vertex method and Eq. (7.2) at the interval values of $\mathrm{r}=[3.3 \% ; 7.4 \%]$ and $\mathrm{T}_{1}=[31,5 ; 47]$ : 


$$
\begin{gathered}
\operatorname{PWF}_{1}(\alpha=0,30)=[\min (0,3596 ; 0,2174 ; 0,1055 ; 0,0349)] \times[\max (0,3596 ; 0,2174 ; 0,1055 ; 0,0349)] \\
\mathrm{PWF}_{1}=[0,0349 ; 0,3596]
\end{gathered}
$$

The NPW is then calculated using the vertex method and Eq. (7.4) as follows:

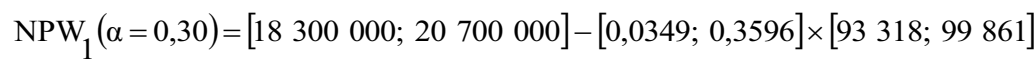

$$
\begin{aligned}
& \mathrm{NPW}_{1}(\alpha=0,30)=\left[\begin{array}{llll}
18 & 296 & 743 ; & 2064090
\end{array}\right]
\end{aligned}
$$

The CRF is calculated using the vertex method and Eq. (7.3) as follows:

$$
\begin{gathered}
\operatorname{CRF}(\alpha=0,30)=[\min (0,0827 ; 0,0767 ; 0,0515 ; 0,0422)] \times[\max (0,0827 ; 0,0767 ; 0,0515 ; 0,0422)] \\
\operatorname{CRF}(\alpha=0,30)=[0,0422 ; 0,0827]
\end{gathered}
$$

The EAC is calculated using the vertex method too and Eq. (7.5) as follows:

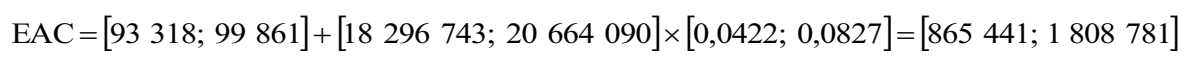

The $\mathrm{R}_{2}$ is calculated using Eq. (7.6):

$$
\mathrm{R}_{2}=1365421 \text { PLN }
$$

The $\mathrm{R}$ value for the second variant is smaller than the first variant.

\section{Conclusions}

The paper presents a short overview of issues involved in the life cycle of buildings. Particular attention was paid to the risks involved in the life cycle costs, presented by means of a method allowing including these risks in the calculation of life cycle costs. The example illustrates two solution variants involving technologies with varying degrees of risk included in the costs incurred. The comparison of the value of the instalments $R$ for both variants reveals that the instalment value for the building implemented in variant 2 is lower than in variant 1 , thus being more advantageous. 


\section{REFERENCES}

1. M. Ammar, T. Zayed, O. Moselhi, "Fuzzy-based life-cycle cost model for decision making under subjectivity", Journal of Construction Engineering and Management 139(5): 556-563, 2012.

2. X. H. An, "Lifecycle management for construction project based on IT", Intelligent Building and Urban Informatization 4: 70-72, 2003.

3. C. Benoît, B. Mazijn, "Guidelines for social life cycle assessment of products", UNEP/SETAC Life Cycle Initiative, Belgium, 2009.

4. A. Boussabaine, R. Kirkham, "Whole Life-Cycle Costing: Risk and Risk Responses". Oxford: Blackwell Publishing Ltd., 2008.

5. D. M. Frangopol, K. Y. Lin, A. C. Estes, "Life-cycle cost design of deteriorating structures", Journal of Structural Engineering 123(10): 1390-1401, 1997.

6. A. Fojud, "Modelowanie cyklu życia produktu realizowanego w ramach przedsięwzięcia budowlanego", In O. Kapliński (red.), "Metody i modele badań w inżynierii przedsięwzięć budowlanych". Warszawa: PAN KILiW, IPPT, 2007.

7. S. K. Fuller, A. S. Boyles, "Life-cycle costing workshop for energy conservation in buildings: Student manual". Gaithersburg, USA, 2000.

8. H. Guo, H. Li, M. Skitmore, "Life-Cycle Management of Construction Projects Based on Virtual Prototyping Technology", Journal of Management in Engineering 26(1): 41-47, 2010.

9. S. A. Hosseinijou, S. Mansour, M. A. Shirazi, "Social life cycle assessment for material selection: a case study of building materials", International Journal of Life Cycle Assessment 19: 620-645, 2014.

10. N. A. Kartam, S. A. Kartam, "Risk and its management in the Kuwaiti construction industry: a contractors' perspective", International Journal of Project Management 19(6): 325-335, 2001.

11. T. Kasprowicz, "Proces analizy koncepcyjnej, projektowania, organizacji i realizacji przedsięwzięć budowlanych", Czasopismo Techniczne. Technical Transactions z.1-B: 177-189, 2010.

12. C. C. Menassa, "Evaluating sustainable retrofits in existing buildings under uncertainty", Energy and Buildings 43(12): 3576-3583, 2011.

13. I. Rybka, E. Bondar-Nowakowska, "Risk of alterations to project documentation on an example of environmental engineering construction", Archives Of Civil Engineering LIX(4): 499-508, 2013.

14. G. Shevchenko, L. Ustinovichius, A. Andruškevičius, "Multi-attribute analysis of investments risk alternatives in construction", Technological and Economic Development of Economy 14(3): 428-443, 2008.

15. J. O. Sobanjo, "Facility life-cycle cost analysis based on fuzzy set theory". Proceedings of the Eighth International Conference on Durability of Building Materials and Components, Vancouver, Canada, Vol. 3: 1798-1809, 1999.

16. A. Tažiková, M. Kozlovská, "Achievement economic and environmental efficiency of construction using the parallel calculating costs". 13th International Multidisciplinary Scientific Geoconference and EXPO, SGEM, Albena, Bulgaria, Vol. 2: 11-18, 2013.

17. A. Tažiková, M. Kozlovská, "Effect of the construction cost calculations to the sustainable development of buildings". Visnik Nacional'nogo universitetu L'vivska politechnika: Teorija i praktika budivnictva, No. 756: 298-303, 2013.

18. J. Teresko, "The PLM Revolution”, Industry Week 253(2): 32-36, 2004.

19. W. Wang, R. Zmeureanu, H. Rivard, “Applying multi-objective genetic algorithms in green building design optimization", Building and environment 40(11): 1512-1525, 2005.

20. I. P. A. Wiguna, S. Scott, "Relating risk to project performance in Indonesian building contracts", Construction Management and Economics 24(11): 1125-1135, 2006.

21. H. Yi, H. Wen-jie, "Analysis of the Life Cycle Cost of the Power Plants Based on Analytic Hierarchy Process Method". Information Management, Innovation Management and Industrial Engineering, International Conference on, IEEE, Vol. 4.: 639-642, 2009.

22. H. Zhi, "Risk management for overseas construction projects", International Journal of Project Management 13(4): 231-237, 1995.

Received 22. 06. 2015

Revised 01. 09. 2015 


\section{LIST OF FIGURES AND TABLES:}

Fig. 1. The information flow of LCM of construction projects

Rys. 1. Przepływ informacji w zarządzaniu cyklem życia projektów budowlanych

Fig. 2. The life cycle of a building

Rys. 2. Cykl życia obiektu budowlanego

Fig. 3. A diagram of a process of determining the life cycle cost of a building, taking into account risk factors Rys. 3. Schemat procesu wyznaczania kosztów cyklu życia obiektów budowlanych z uwzględnieniem wpływu czynników ryzyka

Fig. 4. Trapezoidal membership function with $\alpha$ - cut

Rys. 4. Trapezowa funkcja przynależności w przekroju $\alpha$

Tab. 1. Sample socio-economic factors

Tab. 1. Przykładowe czynniki socjoekonomiczne

Tab. 2. Division of risk factors attributable to individual phases of the life cycle, the case of residential and commercial buildings

Tab. 2. Podział czynników ryzyka ze względu na fazy cyklu życia dla obiektów kubaturowych mieszkalnych i usługowych

Tab. 3. Data used in analysis

Tab. 3. Dane przyjęte do analizy

Tab. 4. Interval values for parameters

Tab. 4. Wartości przedziału dla parametrów 


\section{MODELOWANIE KOSZTÓW CYKLU ŻYCIA OBIEKTÓW BUDOWLANYCH Z UWZGLĘDNIENIEM RYZYKA}

Słowa kluczowe: ocena cyklu życia, koszty cyklu życia, zbiory rozmyte, koszty inwestycyjne

\section{STRESZCZENIE:}

W artykule scharakteryzowano tematykę związaną z cyklem życia obiektów budowlanych. Szczególną uwagę zwrócono na zagadnienia ryzyka związanego z kosztami w cyklu życia. W artykule przedstawiono metodę oceny obiektu budowlanego w cyklu życia, biorącą pod uwagę aspekt jego zrównoważonego rozwoju. Zaprezentowany został model oceny kosztów cyklu życia obiektu budowlanego, który oparty jest na teorii zbiorów rozmytych, co pozwala na uwzględnienie $\mathrm{w}$ obliczeniach czynników ryzyka związanych np. ze zrównoważonym rozwojem, prowadzeniem inwestycji czy poszczególnymi rodzajami kosztów. Koszty ponoszone w kolejnych fazach cyklu życia budynku rozpatrywano i modelowano oddzielnie za pomocą funkcji przynależności. Efektem analizy jest globalna ocena kosztów w ujęciu całego cyklu życia budynku.

W budownictwie podstawowymi fazami realizacji przedsięwzięcia budowlanego są kolejno fazy: programowania, realizacji, eksploatacji oraz wycofania. W przypadku przedsięwzięć budowlanych związanych ze wznoszeniem obiektów mieszkalnych wielorodzinnych, usługowych lub łączących obie funkcje, czynniki ryzyka można zidentyfikować w kolejnych fazach cyklu życia obiektu budowlanego. Szczegółowy podział czynników ryzyka na kategorie ryzyka i występowanie w fazach cyklu życia przedstawiono częściowo w Tabeli 2.

Tabela 2. Podział czynników ryzyka ze względu na fazy cyklu życia dla obiektów kubaturowych mieszkalnych i usługowych; źródło: opracowanie własne na podstawie [10], [14], [20] i [22]

\begin{tabular}{|c|c|c|c|c|c|}
\hline \multirow{2}{*}{$\begin{array}{c}\text { KATEGORIA } \\
\text { RYZYKA }\end{array}$} & \multirow{2}{*}{ CZYNNIKI RYZYKA } & \multicolumn{4}{|c|}{ FAZY CYKLU ŻYCIA } \\
\hline & & $\mathrm{P}$ & $\mathrm{R}$ & $\mathrm{E}$ & W \\
\hline \multirow{3}{*}{ TECHNOLOGICZNE } & błędy w projektach & $\mathrm{X}$ & & & \\
\hline & błędnie rozpoznane warunki gruntowe & $\mathrm{X}$ & & & \\
\hline & ${ }^{\prime} \ldots \ldots \ldots \ldots \ldots \ldots \ldots \ldots \ldots \ldots \ldots \ldots \ldots \ldots \ldots \ldots \ldots \ldots \ldots \ldots \ldots \ldots \ldots \ldots \ldots \ldots \ldots \ldots$ & $\ldots$ & $\ldots$ & $\ldots$ & $\ldots$ \\
\hline \multirow{5}{*}{$\begin{array}{l}\text { BUDOWLANE, } \\
\text { KONSTRUKCYJNE }\end{array}$} & niekorzystne warunki pogodowe & & $\mathrm{X}$ & & $\mathrm{X}$ \\
\hline & zmiany w przewidywanym zakresie prac & & $\mathrm{X}$ & & \\
\hline & opóźnienia w realizacji robót budowlanych & & $\mathrm{X}$ & & $\mathrm{X}$ \\
\hline & zastosowanie materiałów budowlanych deficytowych & & $\mathrm{X}$ & & \\
\hline & 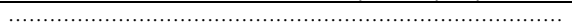 & $\ldots$ & $\ldots$ & $\ldots$ & $\ldots$ \\
\hline \multirow{3}{*}{ FINANSOWE } & brak (lub opóźnienia) zapłaty za wykonane prace & $\mathrm{X}$ & $\mathrm{X}$ & & $\mathrm{X}$ \\
\hline & wzrost cen materiałów budowlanych & & $\mathrm{X}$ & & \\
\hline & 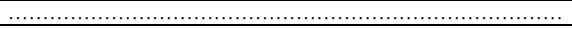 & $\ldots$ & $\ldots$ & $\ldots$ & $\ldots$ \\
\hline \multirow{3}{*}{ POLITYCZNE } & zmiany w systemie podatkowym & $\mathrm{X}$ & $\mathrm{X}$ & $\mathrm{X}$ & $\mathrm{X}$ \\
\hline & spowolnienie rozwoju gospodarczego & $\mathrm{X}$ & $\mathrm{X}$ & $\mathrm{X}$ & $\mathrm{X}$ \\
\hline & 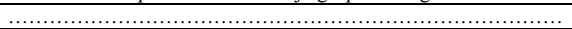 & $\ldots$ & $\ldots$ & $\ldots$ & $\ldots$ \\
\hline \multirow{3}{*}{ EKOLOGICZNE } & błędne założenia projektowe & $\mathrm{X}$ & & & \\
\hline & brak systemu legislacyjnego $\mathrm{w}$ kwestiach środowiskowych & $\mathrm{X}$ & & & \\
\hline & ${ } \ldots \ldots \ldots \ldots \ldots \ldots \ldots \ldots \ldots \ldots \ldots \ldots \ldots \ldots \ldots \ldots \ldots \ldots \ldots \ldots \ldots \ldots \ldots \ldots$ & $\ldots$ & $\ldots$ & $\ldots$ & $\ldots$ \\
\hline \multirow{3}{*}{ PRAWNE } & trudności w uzyskaniu pozwoleń & $\mathrm{X}$ & & & \\
\hline & niezgodność z prawem & $\mathrm{X}$ & $\mathrm{X}$ & & $\mathrm{X}$ \\
\hline & ${ } \ldots \ldots \ldots \ldots \ldots \ldots \ldots \ldots \ldots \ldots \ldots \ldots \ldots \ldots \ldots \ldots \ldots \ldots \ldots \ldots \ldots \ldots \ldots \ldots \ldots \ldots \ldots \ldots$ & $\ldots$ & $\ldots$ & $\ldots$ & $\ldots$ \\
\hline
\end{tabular}

W artykule, na rysunku 3 przedstawiono autorski algorytm postępowania przy wyznaczaniu kosztów cyklu życia obiektu budowlanego, który uwzględnia wpływ zaistniałych czynników ryzyka na wartość kosztów. Algorytm ten służy do oceny scenariuszy cyklu życia i umożliwia porównanie i wybór najlepszej strategii zarządzania obiektem budowlanym w jego cyklu życia. 
W przykładzie porównano koszty cyklu życia budynku wielorodzinnego, uwzględniając główne grupy kosztów (tj. realizacji, eksploatacji, wycofania i zysk z odsprzedaży). Wybrano dwa warianty realizacji budynku.

W pierwszym wariancie budynek realizowany jest w technologii tradycyjnej. Założono więc, że ponoszone koszty można w dużym stopniu przewidzieć. Stąd przyjęto do obliczeń wartości ostre dla kosztów i wyznaczono LCC deterministyczną metodą określania efektywności inwestycji na podstawie zdyskontowanych przepływów pieniężnych z uwzględnieniem kwestii środowiskowych LCNPV - Life Cycle Net Present Value.

W przypadku drugiego wariantu zastosowano w realizacji system HVAC (akronim od angielskiego wyrażenia Heating, Ventilation, Air Conditioning), który odpowiada za regulację ogrzewania, wentylacji i klimatyzacji w budynku. Koszty związane z systemem HVAC są trudne do przewidzenia, ze względu na występujące tu ryzyka. Charakterystycznymi czynnikami ryzyka w analizowanym przypadku mogą być np. zastosowanie rzadkich, specjalistycznych systemów łączących ogrzewanie, wentylację i klimatyzację w fazie realizacji obiektu budowlanego czy ograniczona dostępność specjalistycznych firm serwisujących systemy HVAC. Te uwarunkowania powodują, że wartości kosztów są określone w postaci rozmytej o trapezowym kształcie funkcji przynależności. Dane wyjściowe przyjęte do obliczeń przedstawiono w Tabeli 3 .

Tabela 3. Dane wyjściowe do obliczeń; źródło: opracowanie własne

\begin{tabular}{|c|c|c|c|c|c|}
\hline & \multirow{2}{*}{$\begin{array}{c}\text { WARIANT 1 } \\
\text { Budynek wielorodzinny, } \\
\text { 5-kondygnazyjny w tradycyjnej } \\
\text { technologii }\end{array}$} & \multicolumn{4}{|c|}{$\begin{array}{c}\text { WARIANT 2 } \\
\text { Budynek wielorodzinny, } \\
\text { 5-kondygnazyjny z zastosowaniem systemu HVAC }\end{array}$} \\
\hline & & $\mathrm{L}$ & M1 & M2 & $\mathrm{U}$ \\
\hline Koszty realizacji [PLN] & 13445333 & 18000000 & 19000000 & 20000000 & 21000000 \\
\hline Koszty eksploatacji [PLN] & 210374 na rok & 92512 & 95200 & 99000 & 100230 na rok \\
\hline Koszty wycofania [PLN] & 750190 po 30 latach użytkowania & & & & \\
\hline Zysk z odsprzedaży [PLN] & & 2500000 & 2000000 & 1000000 & 500000 \\
\hline Stopa dyskonta [\%] & 6 & 3 & 4 & 6 & 8 \\
\hline Cykl życia [lata] & 30 & 30 & 35 & 40 & 50 \\
\hline
\end{tabular}

Dla wariantu pierwszego LCNPV wynosi 25368553 PLN, natomiast wartość $\mathrm{R}_{1}$ (zwrot kapitału, który przedstawia wartość LCNPV w postaci ekwiwalentnej wartości kosztów rocznych EAC) wynosi 1842998 PLN.

Wartość obecną czynnika przyszłych przepływów pieniężnych (w kolejnych latach) PWF 1 dla zysku z odsprzedaży obliczono wykorzystując metodę wierzchołka oraz wzór (7.2) w przedziale wartości dla stopy dyskonta $\mathrm{r}=[3.3 \% ; 7.4 \%]$ i czasu $\mathrm{T}_{1}=[31,5 ; 47]$. Otrzymano wynik:

$$
\mathrm{PWF}_{1}=[0,0349 ; 0,3596]
$$

Następnie została obliczona wartość obecna netto NPW w oparciu o tę samą metodę ze wzoru (7.4):

$$
\mathrm{NPW}_{1}(\alpha=0,30)=[18296743 ; 20664090]
$$

Wartość współczynnika zwrotu kapitału CRF obliczono wykorzystując również metodę wierzchołka ze wzoru (7.3):

$$
\operatorname{CRF}(\alpha=0,30)=[0,0422 ; 0,0827]
$$

Ekwiwalentną wartość kosztów rocznych EAC obliczono wykorzystując metodę wierzchołka ze wzoru (7.5):

$$
\mathrm{EAC}=[865441 ; 1808781]
$$

Obliczona wartość $\mathrm{R}$ dla drugiego przypadku wyniosła $\mathrm{R}_{2}=1365421$ PLN i jest ona mniejsza niż wartość $\mathrm{R}_{1}=1842998$ PLN. Rozwiązaniem korzystniejszym dla analizowanego przypadku, z uwagi na LCC jest wariant 2. 